\title{
ダウン症児の発話の不明瞭さと音韻的側面に対する メタ言語意識との関係
}

\author{
高木潤 野*・伊藤 友彦**
}

\begin{abstract}
ダウン症児の発話の不明瞭さと音韻的側面に対するメ夕語語意識との関係を明らかにする ために、モーラへの分節化課題、構音の誤りの自覚課題、扔よび発話速度の自覚課題を用い てダウン症児の音韻的側面に対するメタ言語意識の特徴を検討した。対象児は学齢期のダウ ン症児 16 名および精神年齢を一致させた非ダウン症知的障害児 16 名であった。各音韻的側 面に対するメ夕言語意識課題の成績をダウン症児群と非ダウン症知的障管览群とで比較した ところ、構音の誤りの自覚課題の成績には雨群間で差がみられなかった。しかし発話速度の 自覚課題の成績は、ダウン症児群のほうが非ダウン症知的障害巟群と比較して有意に低かっ た。この結果は、ダウン症児は発話速度に対するメタ言語意識が非ダウン症知的障害児と比 較して低いことを示している。このことから、発話速度に対するメタ言語意識の低さが、ダ ウン症児の発話の不明膫さの要因のひとつである可能性が示唆された。
\end{abstract}

\section{キー・ワード：ダウン症候群 メタ言語意識 発話の不明瞭さ 知的障害 発話速度}

\section{I .はじめに}

ダウン症児の多くは特徴的な発話の不明瞭さを示す ことが知られている (Kumin, 2001; Roberts, Price, \& Malkin, 2007)。ダウン症児・者を子どもにもつ親へ のアンケートを行ったKumin（1994）によると、95\% の親が子どもの発話に不明瞭さがあると回答している という。また、健常児の場合、発達に伴って発話の明 瞭さは向上し、4 歳までに完全な明膫さが獲得される が (Coplan \& Gleason, 1988)、ダウン症児は発話が 完全に明膫沈ることは少なく、発話の不明瞭さは夕゙ ウン症児・者にとっては生涯にわたる問題であること が指摘されている (Kumin, 2006; Shriberg \& Widder, 1990)。

ダウン症児の発話の不明瞭さには、筋緊張の弱さや 口腔の形態の異常等のさまざまな要因がかかわってい ることが指摘されているが (Barnes, Roberts, Mirrett, Sideris, \& Misenheimer, 2006; Kumin, 2001; StoelGammon, 1997)、そのひとつにメ夕言語意識の発達 の遅れが挙げられる (Kennedy \& Flynn, 2003b)。メ 夕言語意識とは、「話すこと」や「話し方」等の言語 に対する意識をいう。発話の音韻的側面に対するメ夕

\footnotetext{
* 長野大学社会福祉学部

** 東京学芸大学教育学部
}

言語意識は、健常児に扔いては 4 歳から 5 歳にかけて 発達することが知ら机ている（伊藤, 1995; 伊藤・辰巳， 1997）。ダウン症児の音韻的側面に対するメ夕言語意 識の発達についてはこれまで、抒もに読み能力との 関係から研究が行われており (Cardoso-Martins, Michalick, \& Pollo, 2002; Cossu, Rossini, \& Marshall, 1993; Cupples \& Lacono, 2000; Gombert, 2002; van Bysterveldt, Gillon, \& Moran, 2006)、ダウン症 児は音韻的側面に対するメ夕言語意識の発達が精神 年齢と比較して遅れることが明らかになっている (Cossu et al., 1993; Kennedy \& Flynn, 2003a; Roch \& Jarrold, 2008; Snowling, Hulme, \& Mercer, 2002; Verucci, Menghini, \& Vicari, 2006)。ダウン症児の 発話の不明膫さと音韻的側面に対するメ夕言語意識と の関係についての研究は少ないものの、Kennedy and Flynn（2003b） は、ダウン症児の音韻的側面に対する メ夕言語意識と読み能力との関係を検討した研究の中 で、メタ言語意識の向上が子音の産出能力の向上に結 びついた者が存在したことを報告している。また石田 （1999）は、単語レベルの発話の明瞭さと音韻的側面 に対するメタ言語意識との関係について検討し、語の 分節化能力と発話の明瞭さとの間には弱い相関がみら れたことを報告している。

しかしこれまで、ダウン症児の発話の不明瞭さと音 
Table 1 対象児の MA および CA の平均と SD

\begin{tabular}{lccc}
\hline & 人数 (男, 女) & 平均 $\mathrm{MA} \pm S D$ & 平均 $\mathrm{CA} \pm S D$ \\
\hline ダウン症児群 & $16(13,3)$ & $3: 9 \pm 0: 10$ & $14: 8 \pm 2: 1$ \\
非ダウン症知的障害览群 & $16(12,4)$ & $4: 2 \pm 1: 1$ & $14: 4 \pm 1: 8$ \\
\hline
\end{tabular}

韻的傾面に対するメ夕言語意識との関係について、詳 細な研究は行われていない。ダウン症児の発話の不明 瞭さと音韻的側面に対するメ夕言語意識との関係を明 らかにするためには、ダウン症児の音韻的側面に対す るメ夕言語意識の特徵を明らかにすることが求められ る。発話の不明膫さはダウン症览だけでなく非ダウン 症知的障害児にもみられる問題であることから (Fowler, 1998; Paul, Cohen, Breg, Watson, \& Herman, 1984; Rondal, 2001)、ダウン症児の発話の不明瞭さと 音韻的側面に対するメ夕言語意識との関係を明らかに するためには、非ダウン症知的障害児と比較すること によってダウン症児の音韻的側面に対するメ夕言語意 識の特徴を明らかにすることが必要であると考えられ る。しかし、ダウン症児が非ダウン症知的障害児と比 較して音韻的側面に対するメ夕言語意識にどのような 違いを有するかについては、これまで研究が行われて いない。

そこで本研究では、ダウン症児と非ダウン症知的障 害児とを比較することで、ダウン症児の音韻的側面に 対するメ夕言語意識の特徴を明らかにすることを目的 とする。

\section{II. 方 法}

\section{1. 対象児}

中学校特別支援学級および特別支援学校中学部・高 等部に在籍する、ダウン症児および非ダウン症知的障 害児を対象とした。対象児の人数は、精神年齢 (MA)、

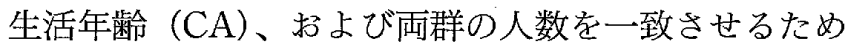
に、人数の少なかった非多ウン症知的障害児群にあわ せ、いずれの群も16 名とした。Table 1 は対象児の MA 抢よび CA の平均と、それぞれの SD を示したも のである。対象児の MA は田中ビネー知能検查 Vに よって測定されたものを用いた。対象児はすべて音声 言語によるコミュニケーションが可能であり、行動観 察から聴力は日常生活に支障がないと判断された。

\section{2. 手続き}

メ夕言語意識の発達をどのような方法で測定するか という点については、ダウン症児のメタ言語意識の発 達の研究においてさまざまな議論が行われている
(Cardoso-Martins \& Frith, 2001; Cossu et al., 1993; Kennedy \& Flynn, 2003a; Roch \& Jarrold, 2008; Snowling et al., 2002; Verucci et al., 2006)。しかし、 ダウン症児のメ夕言語意識については招もに英語を母 語とする者について研究が行われており、脚韻への意 識や語頭の子音への意識など、日本語母語話者を対象 とする研究には直接使用できない方法が多く用いられ ている。このため本研究では、日本語を母語とする対 象児に使用可能な方法として、伊藤（1995）および伊 藤・辰巳（1997）参考に、モーラへの分節化課題、 構音の誤りに対するメ夕言語意識課題、および発話速 度に対するメ夕言語意識課題を行った。

また不明瞭語の生起率を算出するために、自然発話 の収集を行った。課題はすべて個別に行い、発話はす べてテープレコーダーによって録音した。発話の収集 では、乗り物等の絵やアニメのキャラクターが描かれ た絵を呈示し、何が描かれているかを叙述させ、1名 の対象児につき 100 発話を収集した。自然に発せられ た発話を原則としたが、発話を促すために検查者があ いづちを打ったり話しかけた場合もあった。

（1）モーラへの分節化課題：刺激語は、練習用 の刺激語として特殊拍を含まない 2 モーラ語 (くつ) 1 語、本課題用の刺激語として特殊拍を含む 2 モーラ語 (ぱん、ほん）および6モーラ語（アンパンマン、バイ キンマン) 各 2 語を用いた。はじめに練習用として、 特殊拍を含まない 2 音節の刺激語の描かれた絵カード を呈示し、絵の呼称を促した。その後、「く、つ」と モーラごとに区切った発音の例を示し、「このように ひとつずつ切って言ってください」と教示した。次 に、本課題用の特殊拍を含む刺激語の措かれた絵力ー ドを呈示し、「同じようにひとつずつ切って言ってく ださい」と教示した。区切り方がはっきりしない場合 は「もっとしっかり切って言ってください」と教示 し、再度試みさせた。課題は 1 音節 2 モーラ語、 3 音 節 6 モーラ語の順に実施した。

(2) 構音の詔りの自覚課題：刺激語は、Table 2 に示した 2 語を用いた。はじめに刺激語「すいか」 の描かれた絵カードを呈示し、次のように教示した。 「これから絵の名前を言います。上手に言えるかどう 
Table 2 刺激語と呈示した言い方

\begin{tabular}{lll}
\hline \multicolumn{1}{c}{ 言い方 } & すいか & りんご \\
\hline 構音の誤りを含まない言い方 & すいか & りんご \\
構音の誤りを含む言い方 & しゅいた* & じんど \\
\hline & $*$ & は構意の悞りを示す.
\end{tabular}

かよく聴いて、おかしかったらおかしいと言ってくた さい」。その後、Table 2 に示した言い方による呈示 を行った。課題は、構音の誤りを含まない言い方、構 音の愦りを含む言い方の順で行い、「りんご」につい ても同様に実施した。

(3) 発話速度の自覚課題：刺激語は「こんにち は」および「さようなら」の 2 語を用い、2 語それぞ れにつき「通常の速さでの言い方」および「早口での 言い方」の 2 通りの言い方による呈示を行った。早口 での言い方は、構音やモーラ数は変化させず、発話速 度のみを変化させた言い方で呈示した。はじめに動物 の絵を呈示し、「これから動物が挨拶をします。上手 に言えるかどうかよく聴いて、おかしかったらおかし いと言ってください」と教示した。その後、刺激語 「こんにちは」について、通常の速さでの言い方、早 口での言い方、の順に呈示を行った。「さようなら」 についても同様に実施した。

\section{3. 不明瞭語の分析}

ダウン症児の発話の不明瞭さについては、従来の研 究において共通の分析方法が存在するわけではないも のの、多くの場合、話し手の意図が他者によってどの 程度理解されるかという視点から発話の不明瞭さをと らえてきた。本研究では従来の研究における定義を参
考に、発話の不明瞭さを以下のように分析した。ま ず、「産出状況からみてその音形が語を表示している と判断できるが、産出された音形から目標語が推測で きないもの」を不明膫語として分類した。さらに、産 出された総文節数に占める不明瞭語の生起数を、発話 の不明瞭さの指標として用いた。不明瞭語の算出は文 節単位で行った。

なお、不明瞭語の同定は筆者が行ったが、無作為に 抽出したサンプルについて、もう 1 名の評定者との間 の一致度を算出した。その結果、発話の不明瞭さの一 致度は $90.1 \%$ であった。

一致度 $(\%)=$

$$
\frac{\text { 一致した反応数 }}{\text { 一致した反応数十不二致であった反応数 }} \times 100
$$

\section{III. 結 果}

\section{1. ダウン症児群と非ダウン症知的障害児群との不 明瞭語の生起率の比較}

Fig. 1 は、自然発話に扔ける不明瞭語の生起率の平 均を、ダウン症児群と非ダウン症知的障害児群とで比 較して示したものである。縦軸は不明睹語の生起率を 示している。この図から、非ダウン症知的障害児群と 比較して、ダウン症児群のほうが不明瞭語の生起率が 高い傾向を示したことがわかる。数值を角変換して $t$ 検定を行った結果、平均の差は有意であった $(t(30)=$ $2.65, p<.05)$ 。

Fig. 2 は、自然発話における個人別の不明瞭語の生 起率を、ダウン症児群と非ダウン症知的障害児群とで 比較して示したものである。縦軸は不明瞭語の生起率 を示している。この図から、いずれの群においても、

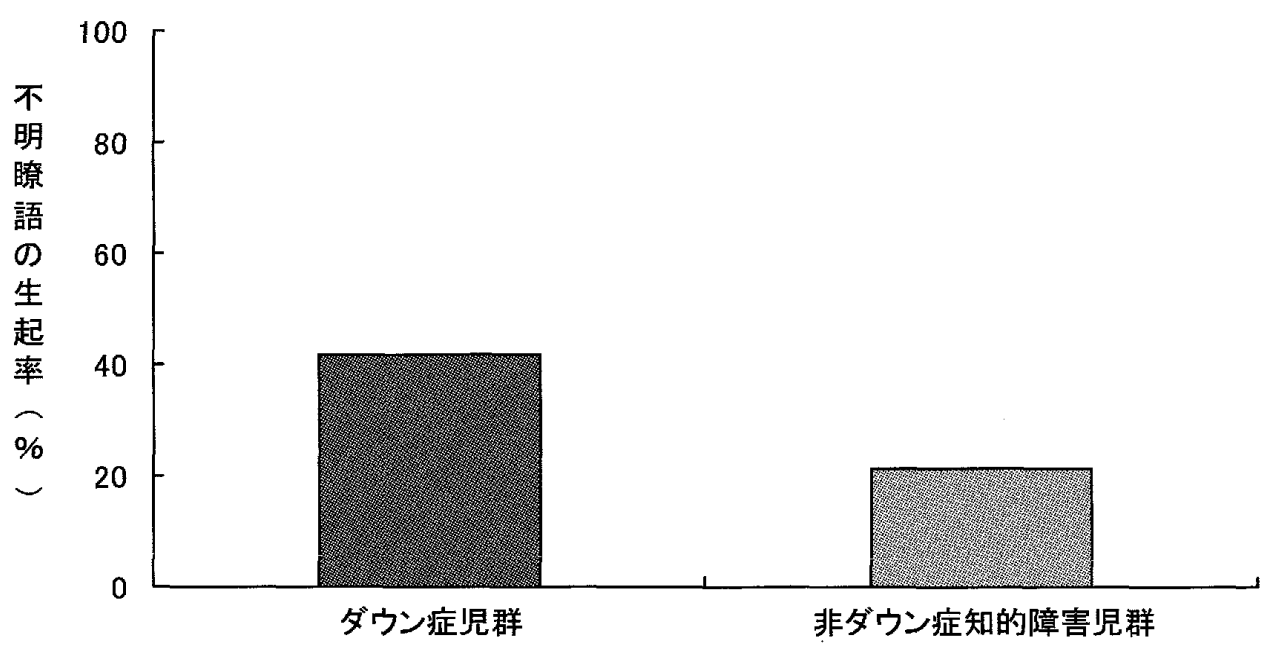

Fig. 1 不明瞭語の生起率の平均の比較 
不明瞭語の生起率は高い傾向を示す者から低い傾向を 示す者まで存在したことがわかる。またダウン症児群 においては、不明瞭語の生起率が高い者が非ダウン症 知的障害览群と比較して多い傾向がみられ、ダウン症 児群の対象児においては不明瞭語の生起率が $50 \%$ 以 上であった者が 16 名中 8 名であったのに対し、非夕゙ ウン症知的障害児群の対象児では 2 名であった。

\section{2. ダウン症児群と非ダウン症知的障害児群とのメ}

\section{夕言語意識課題の成績の比較}

Table 3 は、モーラへの分節化課題の成績につい て、各群の人数分布を示したものである。各課題にお いて正答であった反応が 1 語以上あった場合に分節化 可能であると分類した。この表から、ダウン症览群は 分節化不可能であった者が多い傾向がみられたの注対 し、非ダウン症知的障害巟群は可能であった者が多い
傾向がみられた。直接確率計算の結果、人数の偏りは 有意傾向であった $(p=.08)$ 。

Table 4 は、構音の誤りの自覚課題の成績につい て、各群の人数分布を示したものである。各課題にお いて正答であった反応が 1 語以上あった場合に、構音 の誤りの自覚が可能であると分類した。この表から、 ダウン症児群と比較して、非ダウン症知的障害児群の ほうが構音の䛊りの自覚が可能であった者が多い傾向 がみられた。しかし、直接確率計算の結果、人数の偏 りは有意でなかった $(p=.23)$ 。

Table 5 は、発話速度の自覚課題の成績について、 各群の人数分布を示したものである。各課題において 正答であった反応が 1 語以上あった場合に、発話速度 の自覚が可能であると分類した。この表から、ダウン 症児群は発話速度の自覚が不可能であった者が多い傾
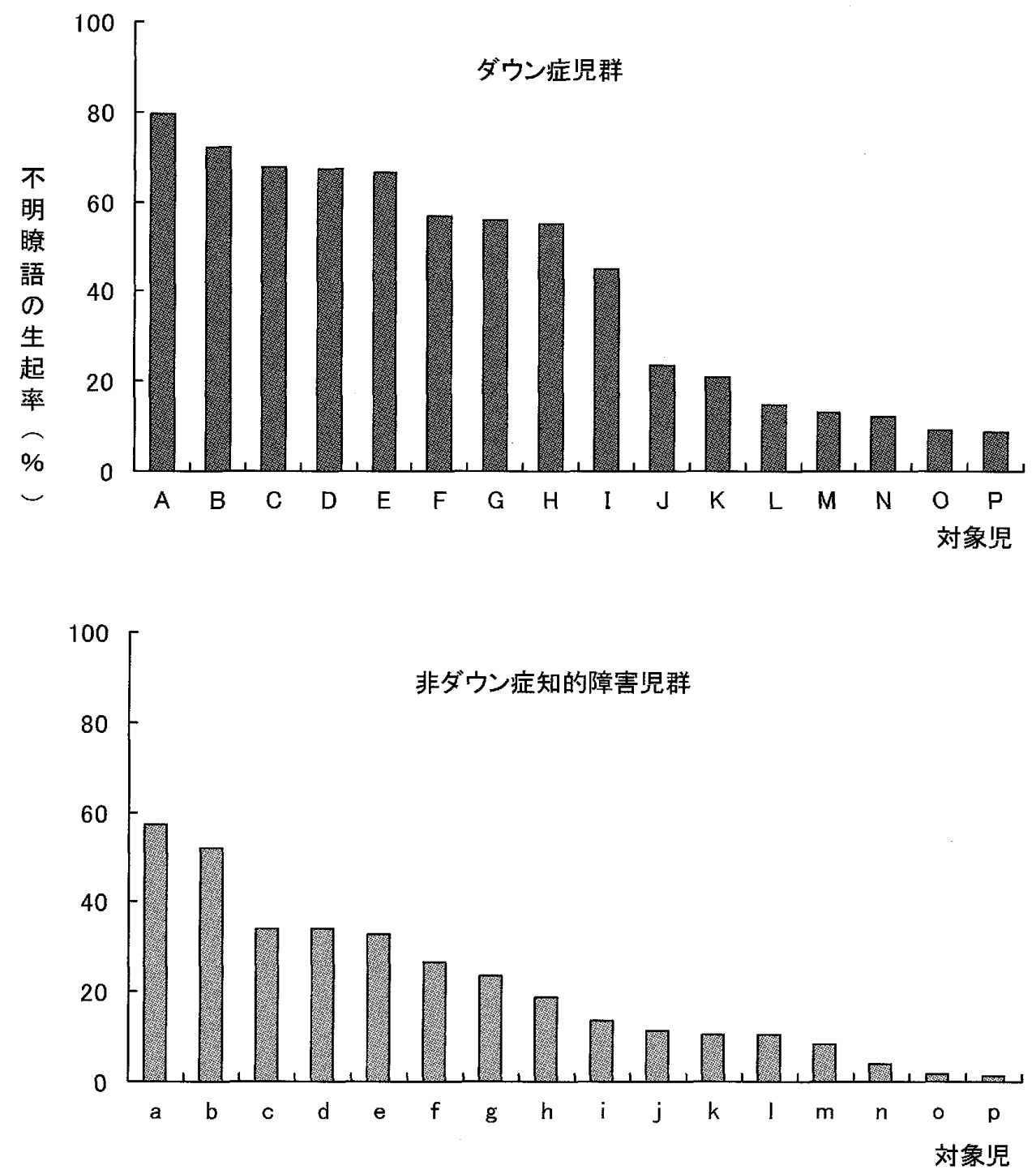

Fig. 2 個人別の不明瞭語の生起率の比較 
Table 3 モーラへの分節化課題の成績

\begin{tabular}{lcc}
\hline & $\begin{array}{c}\text { 分節化可能** } \\
\text { (人) }\end{array}$ & $\begin{array}{c}\text { 分節化不可能 } \\
\text { (人) }\end{array}$ \\
\hline ダウン症児群 & 5 & 11 \\
非ダウン症知的障害児群 & 10 & 6 \\
\hline
\end{tabular}

*各課題において正答であった反応が 1 語以上㐫った者 を分節化可能とした。

Table 4 構音の誤りの自覚課題の成績

\begin{tabular}{lcc}
\hline & $\begin{array}{c}\text { 自覚可能* } \\
\text { (人) }\end{array}$ & $\begin{array}{c}\text { 自覚不可能 } \\
\text { (人) }\end{array}$ \\
\hline ダウン症児群 & 9 & 7 \\
非ダウン症知的障害児群 & 12 & 4 \\
\hline
\end{tabular}

*各課題に招いて正答で亦った反応が 1 語以上あった者 を自覚可能とした。

向がみられたのに対し、非ダウン症知的障害児群は可 能であった者が多い傾向がみられた。直接確率計算の 結果、人数の偏りは有意であった $(p=.03)$ 。

\section{IV. 考 察}

本研究では、ダウン症児と非ダウン症知的障害児と で音韻的側面に対するメ夕言語意識に差がみられるか どうかを明らかにすることを目的として、モーラへの 分節化課題、構音の誤りの自覚課題、および発話速度 の自覚課題を用いてダウン症児と非ダウン症知的障害 児とで比較を行った。その結果、以下の点が明らかに なった。

自然発話に扔ける不明瞭語の生起率をダウン症巟群 と非ダウン症知的障害肾群とで比較したところ、ダウ ン症児群の䚾うが不明瞭語の生起率が有意に高かっ た。また不明膫語の生起率の個人別の比較において も、非ダウン症知的障害児群と比較してダウン症児群 のほうが、不明瞭語の生起率が高い者が多い傾向がみ られた。発話の不明瞭さは、ダウン症児だけでなくダ ウン症を伴わない知的障害児にもみられる問題である ことが指摘されてきたが (Fowler, 1998; Paul et al., 1984; Rondal, 2001)、本研究の結果、精神年齢が同程 度である非ダウン症知的障害児と比較してダウン症児 のほうが発話が不明瞭であることが示された。

各メ夕言語意識課題の成績をダウン症児群と非ダウ ン症知的障害児群とで比較したところ、構音の誤りの 自覚課題の成績についてはダウン症児群と非ダウン症 知的障害児群は有意差がみられず、モーラへの分節化
Table 5 発話速度の自覚課題の成績

\begin{tabular}{lcc}
\hline & $\begin{array}{c}\text { 自覚可能* } \\
\text { (人) }\end{array}$ & $\begin{array}{c}\text { 自覚不可能 } \\
\text { (人) }\end{array}$ \\
\hline ダウン症児群 & 3 & 13 \\
非ダウン症知的障害児群 & 9 & 7 \\
\hline
\end{tabular}

*各課題において正答であった反応が 1 語以上あった者 を自覚可能とした。

課題の成績については、両群の差は有意傾向であつ た。しかし発話速度の自覚課題の成績については、非 ダウン症知的障害児群と比較してダウン症児群のほう が有意に低かった。これらの課題の成績から、ダウン 症児は構音の誤りに対するメ夕言語意識については非 ダウン症知的障害児と差がみられないが、発話速度に 対するメ夕言語意識については非ダウン症知的障害児 と比較して低いことが示唆された。

ダウン症児の発話の不明瞭さの要因のひとつとし て、音韻的側面に対するメ夕言語意識の遅れがかかわ っている可能性が指摘されているが (Kennedy \& Flynn, 2003b)、これまでダウン症児が非ダウン症知 的障害児と比較して音韻的側面に対するメ夕言語意識 にどのような特徴を有するかについては研究が行われ てこなかった。本研究の結果からダウン症児は、発話 速度に対するメ夕言語意識が非ダウン症知的障害児と 比較して低いことが明らかになった。このことから、 発話速度に対するメ夕言語意識の低さが、ダウン症児 の発話の不明瞭さにかかわっている可能性が示唆さ れる。

発話の速度が速いということは、ダウン症児の発話 の音韻的特徵のひとつとして従来から指摘されている 問題である (Cabanas, 1954; Farmer \& Brayton, 1979; Otto \& Yairi, 1974; Van Borsel \& Tetnowski, 2007)。またダウン症児の多くが早口症を有している ことも知られている (Preus，1972; Van Borsel \& Vandermeulen, 2008)。しかし、ダウン症児の発話速 度と発話の不明膫さとの関係については、いくつかの 研觉にお゙いて言及されているのみで（Farmer \& Brayton, 1979; Otto \& Yairi, 1974)、ほとんど研究が 行わ机ていない。本研究の結果、発話速度に対するメ 夕言語意識の低さがダウン症児の発話の不明瞭さにか かわっている可能性が示唆された。このことから、ダ ウン症児の発話速度とメ夕言語意識との関係をより 詳細に検討することが、今後の課題となると考えら れる。 


\section{文 献}

Barnes, E. F., Roberts, J., Mirrett, P., Sideris, J., \& Misenheimer, J. (2006) A comparison of oral structure and oral-motor function in young males with fragile $\mathrm{X}$ syndrome and Down syndrome. Journal of Speech and Hearing Research, 49, 903-917.

Cabanas, R. (1954) Some findings in speech and voice therapy among mentally deficient children. Folia Phoniatrica, 6, 34-37.

Cardoso-Martins, C. \& Frith, U. (2001) Can individuals with Down syndrome acquire alphabetic literacy skills in the absence of phoneme awareness? Reading and Writing: An Interdisciplinary Journal, 14, 361375.

Cardoso-Martins, C., Michalick, M. F., \& Pollo, T. C. (2002) Is sensitivity to rhyme a developmental precursor to sensitivity to phoneme?: Evidence from individuals with Down syndrome. Reading and Writing: An Interdisciplinary Journal, 15, 439-454.

Coplan, J. \& Gleason, J. R. (1988) Unclear speech: Recognition and significance of unintelligible speech in preschool children. Pediatrics, 82, 447-452.

Cossu, G., Rossini, F., \& Marshall, J. C. (1993) When reading is acquired but phonemic awareness is not: $\mathrm{A}$ study of literacy in Down's syndrome. Cognition, 46, 129-138.

Cupples, L. \& Lacono, T. (2000) Phonological awareness and oral reading skill in children with Down syndrome. Journal of Speech, Language, and Hearing Research, 43, 595-608.

Farmer, A. \& Brayton, E. R. (1979) Speech characteristics of fluent and dysfluent Down's syndrome adults. Folia Phoniatrica, 31, 284-290.

Fowler, A. E. (1998) Language in mental retardation: Associations with and dissociations from general cognition. In J. A. Burack, R. M. Hodapp, \& E. Zigler (Eds.), Handbook of mental retardation and development. Cambridge University Press, Cambridge, England, 290-333.

Gombert, J. E. (2002) Children with Down syndrome use phonological knowledge in reading. Reading and Writing: An Interdisciplinary Journal, 15, 455469.

石田宏代（1999）ダウン症児の発語の明膫さと音韻意 識との関連. 特殊教育学研究, 36(5), 17-23.
伊藤友彦 (1995) 構音, 流暢性に対するメ夕言語知識の 発達, 音声言語医学, 36, 235-241.

伊藤友彦・辰巳 格（1997）特殊拍に対するメ夕言語 知識の発達. 音声言語医学, 38, 196-203.

Kennedy, E. J. \& Flynn, M. C. (2003a) Early phonological awareness and reading skills in children with Down syndrome. Down Syndrome Research and Practice, 8(3), 100-109.

Kennedy, E. J. \& Flynn, M. C. (2003b) Training phonological awareness skills in children with Down syndrome. Research in Developmental Disabilities, 24, 44-57.

Kumin, L. (1994) Intelligibility of speech in children with Down syndrome in natural setting: Parents' perspective. Perceptual and Motor Skills, 78, 307313.

Kumin, L. (2001) Speech intelligibility in individuals with Down syndrome: A framework for targeting specific factors for assessment and treatment. Down Syndrome Quarterly, 6(3), 1-8.

Kumin, L. (2006) Speech intelligibility and childhood verbal apraxia in children with Down syndrome. Down Syndrome Research and Practice, 10(1), 1022.

Otto, F. M. \& Yairi, E. (1974) An analysis of the speech dysfluencies in Down's syndrome and in normally intelligent subjects. Journal of Fluency Disorders, 1, 26-32.

Paul, R., Cohen, D. J., Breg, W. R., Watson, M., \& Herman, S. (1984) Fragile-X syndrome: Its relation to speech and language disorders. Journal of Speech Disorders, 49, 326-336.

Preus, A. (1972) Stuttering in Down's syndrome. Scandinavian Journal of Educational Research, 16 (2-3), 89-104.

Roberts, J. E., Price, J., \& Malkin, C. (2007) Language and communication development in Down syndrome. Mental Retardation and Developmental Disabilities, 13, 26-35.

Roch, M. \& Jarrold, C. (2008) A comparison between word and nonword reading in Down syndrome: The role of phonological awareness. Journal of Communication Disorders, 41, 305-318.

Rondal, J. A. (2001) Language in mental retardation: Individual and syndromic differences, and neuro- 
genetic variation. Swiss Journal of Psychology, 60, 161-178.

Shriberg, L. D. \& Widder, C. J. (1990) Speech and prosody characteristics of adults with mental retardation. Journal of Speech and Hearing Research, 33, 627-653.

Snowling, M. J., Hulme, C., \& Mercer, R. C. (2002) A deficit in rime awareness in children with Down syndrome. Reading and Writing: An Interdisciplinary Journal, 15, 471-495.

Stoel-Gammon, C. (1997) Phonological development in Down syndrome. Mental Retardation and Developmental Disabilities, 3, 300-306.

Van Borsel, J. \& Tetnowski, J. A. (2007) Fluency disorders in genetic syndromes. Journal of Fluency Disorders, 32, 279-296.

Van Borsel, J. \& Vandermeulen, A. (2008) Cluttering in Down syndrome. Folia Phoniatrica, 60, 312-317. van Bysterveldt, A. K., Gillon, G. T., \& Moran, C. (2006) Enhancing phonological awareness and letter knowledge in preschool children with Down syndrome. International Journal of Disability, Development and Education, 53, 301-329.

Verucci, L., Menghini, D., \& Vicari, S. (2006) Reading skills and phonological awareness acquisition in Down syndrome. Journal of Intellectual Disability Research, 50, 477-491.

- - 2008.10.2 受稿, 2009.8.22 受理一 


\title{
Relation Between Speech Unintelligibility and Phonological Awareness: Children With Down Syndrome
}

\author{
Junya TAKAGI* and Tomohiko ITO** \\ * Faculty of Social Welfare, Nagano University \\ (Ueda-Shi, 386-1298) \\ **Department of Education for Children With Disabilities, Tokyo Gakugei University
}

(Koganei-Shi, 184-8501)

\begin{abstract}
The present study aimed to investigate the relation between speech unintelligibility and phonological awareness in children with Down syndrome. The participants were 16 children with Down syndrome (average chronological age, 14.8 years; average mental age, 3.9 years), and 16 mental-age-matched children with mental retardation but without Down syndrome (average chronological age, 14.4 years; average mental age, 4.2 years). All participants were individually administered 3 tasks for the evaluation of phonological awareness: a moraic-segmentation task, an awareness-of-articulation-errors task, and an awareness-of-speaking-rate task. In the moraic-segmentation task, stimulus words were presented to the participants, who were instructed to divide the words into mora. In the awareness-of-articulation-errors task, stimulus words either with or without articulation errors were presented, and participants were asked whether the stimulus words were odd. In the awareness-of-speaking-rate task, stimulus words were presented at either a normal or a fast speaking rate, and participants were asked whether the stimulus words were odd. No significant differences were found between the 2 groups in terms of performance on the moraic-segmentation and awareness-of-articulation-errors tasks. However, the children with Down syndrome showed significantly lower performance on the awareness-of-speaking-rate task than the children without Down syndrome. These results suggest that there may be a relation between speech unintelligibility in children with Down syndrome and their awareness of speaking rate.
\end{abstract}

Key Words: speech unintelligibility, phonological awareness, speaking rate, children with Down syndrome, children with mental retardation 